\title{
Lymphocyte Proliferative Responses to Human Immunodeficiency Virus Antigens In Vitro
}

\author{
John F. Krowka," Daniel P. Stites," Sharad Jain," Kathelyn S. Steimer," Carlos George-Nascimento," Alex Gyenes,” \\ Philip J. Barr," Harry Hollander," Andrew R. Moss," Jacques M. Homsy," Jay A. Levy," and Donald I. Abrams"s! \\ *Departments of Laboratory Medicine, ${ }^{\S}$ Medicine, "Epidemiology and International Health, and "the Cancer Research Institute of the \\ University of California, San Francisco, California 94143-0100; and ${ }^{\ddagger}$ The Chiron Corporation, Emeryville, California 94608
}

\begin{abstract}
All HIV seronegative (HIV Ab-) and most HIV seropositive (HIV Ab+) individuals' lymphocytes failed to proliferate in primary cultures in response to purified HIV or to recombinant envelope and core antigens of $\mathrm{HIV}$, even in the presence of recombinant interleukin 2 (rIL-2). Most HIV Ab- and HIV Ab+ individuals' lymphocytes, however, could proliferate or be induced by rIL-2 to proliferate in response to lysates of Escherichia coli or Saccharomyces cerevisiae. These findings indicate selective defects in lymphocyte proliferative responses to HIV antigens before the development of AIDS in which lymphocytes are unable to proliferate in response to any antigens. These defects in cell-mediated immune responses to HIV antigens are likely to play an important role in the pathobiology of HIV infections. Although intact HIV or glycosylated gp120 envelope protein of HIV are involved in these defects, a nonglycosylated recombinant form of the HIV gp120 envelope (ENV2-3) and p25 core proteins did not inhibit antigen- or mitogen-driven lymphocyte proliferation.
\end{abstract}

\section{Introduction}

Infection by HIV may result in a state of asymptomatic seropositivity, a variety of AIDS-related conditions (ARC), ${ }^{1}$ or AIDS (1). In the natural course of HIV infection, most individuals will ultimately develop ARC or AIDS (2). Cytopathic or inhibitory effects of HIV on T cells and macrophages that express the CD4 differentiation antigen play a central role in many of the immunological defects of HIV-infected individuals (3-9). The progressive accumulation of these defects in HIV-infected patients permits the development of infectious and neoplastic diseases.

The immune system does not passively accept these insults that are inflicted by HIV, but produces specific antibodies and

Address correspondence to Dr. John F. Krowka, Department of Laboratory Medicine, Box 0100, University of California, San Francisco, CA 94143.

Received for publication 27 May 1988 and in revised form 4 November 1988.

1. Abbreviations used in this paper: $\mathrm{Ab}+$, antibody positive; $\mathrm{Ab}-$, antibody negative; ARC, AIDS-related conditions; CMV, cytomegalovirus; gp120, 120-kD envelope glycoprotein of HIV; rIL-2, recombinant IL-2; SI, stimulation index of proliferation; TT, tetanus toxoid; $\overline{\mathrm{X}}$, mean.

J. Clin. Invest.

(c) The American Society for Clinical Investigation, Inc.

0021-9738/89/04/1198/06 \$2.00

Volume 83, April 1989, 1198-1203 cell-mediated responses in an attempt to control this virus (9-19). Both proliferative and cytotoxic lymphocyte responses to products of the gag, pol, or env genes of HIV have been reported $(9,15,16,18,19)$. Very little is known, however, of the roles of adaptive immune responses, particularly of cellmediated responses to specific HIV antigens, in controlling the pathogenesis of HIV infections. Cell-mediated immunity appears to be important in controlling other types of viral infections (20-22), suggesting that some of these types of responses may also be beneficial to HIV-infected individuals.

The studies described in this report characterize lymphocyte proliferation in response to purified HIV and its subunits as an index of cell-mediated immune responses in HIV-infected individuals. As an extension of our previous studies demonstrating the immunosuppressive properties of HIV or its subunits in vitro (5), the nonglycosylated ENV2-3 and core (p25) recombinant proteins of $\operatorname{HIV}(10,11,14)$ were also tested for their ability to inhibit antigen- and mitogen-driven lymphocyte proliferation. Additional analysis to elucidate the effects of HIV-antigens on cell-mediated immune responses hopefully will facilitate manipulation of these responses to prevent or treat HIV infections.

\section{Methods}

Study subjects. Asymptomatic HIV seronegative (Ab-) and HIV seropositive $(\mathrm{Ab}+)$ males were hospital personnel and homosexual men participating in an epidemiologic study of AIDS (2). Patients with ARC or AIDS (1) were recruited from the Adult Immune Deficiencies Clinic of the University of California, San Francisco, and Ward 86 of the San Francisco General Hospital. Patients with ARC were all HIV $\mathrm{Ab}+$ homosexual or bisexual males with a wide variety of HIV-related symptoms including lymphadenopathy, fevers, diarrhea, oral candidiasis or leucoplakia, sweats, unexplained weight loss, or neurologic manifestations. No subjects were receiving antiviral agents or chemotherapy at the time of blood collection. Antibodies to HIV were determined by ELISA (Abbott Laboratories, North Chicago, IL) and confirmed by Western blot or indirect immunofluorescent analysis (12, 13). Phenotypic analysis of CD4+ and CD8+ lymphocytes was performed as described (5).

Antigens and mitogens. The HIV-SF2 isolate (23) of HIV-1 was purified from supernatants of persistently infected HUT-78 cells as described previously (24). This purified virus and concentrated supernatants of uninfected HUT- 78 cells were treated for $30 \mathrm{~min}$ at $56^{\circ} \mathrm{C}$. Protein concentrations were determined by absorbance at $280 \mathrm{~nm}$ using BSA as a standard. Recombinant p25 protein of HIV-SF2 was expressed in Escherichia coli and purified as described (10). Recombinant envelope proteins of HIV-SF2 were expressed in Saccharomyces cerevisiae and purified as described (11). Recombinant ENV-1, ENV2-3, and ENV-5 constitute amino acids 26-276, 26-510, and 557-677 of HIV-SF2, respectively (11, and unpublished observations). Control proteins $(10,11)$ of $E$. coli, $S$. cerevisiae, and SOD were used to verify the specificity of proliferative responses to recombinant HIV antigens that were $>95 \%$ pure as determined by staining of electro- 
phoresed samples with Coomassie blue. Tetanus toxoid (TT) was obtained from the Massachusetts Department of Public Health (Boston, MA) and PHA from Gibco Laboratories (Grand Island, NY).

Analysis of stimulation or inhibition of lymphocyte proliferation in primary in vitro cultures. Lymphocyte proliferation was performed as described previously (5). Briefly, $10^{5}$ PBMC were cultured in the presence or absence of a wide concentration range $(0.01,0.1,1,10$, and 20 $\mu \mathrm{g} / \mathrm{ml}$ ) of HIV or control antigens in $0.2 \mathrm{ml}$ of RPMI 1640 medium containing 10\% HIV Ab- human AB serum (Gemini Bio-Products, Calabasas, CA) and antibiotics. Optimal proliferation occurred in nearly all study subjects at antigen concentrations of 10 or $20 \mu \mathrm{g} / \mathrm{ml}$ (unpublished observations). Parallel cultures also contained an optimal submitogenic concentration $(5 \mathrm{U} / \mathrm{ml})$ of human rIL-2 that augmented proliferation of PBMC from HIV Ab+ individuals in the presence of cytomegalovirus (CMV) antigen but not in its absence (5). Units of IL-2 were quantitated by determining the dilution of rIL-2 that resulted in significant proliferation $(P<0.003)$ of IL-2-dependent CTLL cells (25). After $7 \mathrm{~d}$, cultures were pulsed for $6 \mathrm{~h}$ with $1 \mu \mathrm{Ci}$ $\left[{ }^{3} \mathrm{H}\right]$ thymidine (ICN Radiochemicals, Irvine, CA) and harvested. Previous analysis at days $3,5,7,9$, and 11 after the initiation of culture demonstrated optimal proliferation at day 7 (not shown). The mean $(\overline{\mathrm{X}})$ background $\mathrm{cpm}$ of $\left[{ }^{3} \mathrm{H}\right]$ thymidine incorporated in the absence of antigen(s) varied between 150 and $950 \mathrm{cpm}$. SD of the mean of quadruplicate cultures were $<15 \%$. Stimulation indices (SI) of proliferation were calculated by the following formula:

$\mathrm{SI}=\frac{\overline{\mathrm{X}} \mathrm{cpm}\left[{ }^{3} \mathrm{H}\right] \mathrm{thymidine} \text { incorporated with antigen }}{\overline{\mathrm{X}} \mathrm{cpm}\left[{ }^{3} \mathrm{H}\right] \text { thymidine incorporated without antigen }}$

Proliferative responses of PBMC to HIV antigens that were $>3$ SD above the $\overline{\mathrm{X}}$ proliferative responses of HIV $\mathrm{Ab}-$ individuals were considered to be positive. For the analysis of possible inhibitory effects of recombinant ENV2-3 or p25 proteins, $1-20 \mu \mathrm{g} / \mathrm{ml}$ of these proteins were added to cultures of $10^{5} \mathrm{TT}(2.5 \mathrm{Lf} / \mathrm{ml})$ - or PHA (1\%)-stimulated PBMC from HIV Ab-donors and analyzed as described above. The significance of differences between proliferative responses was evaluated using $t$ test.

\section{Results}

Purified HIV-SF2 does not stimulate proliferation of lymphocytes from most HIV Ab+ asymptomatic individuals. Lymphocytes from HIV $\mathrm{Ab}-$ and $\mathrm{HIV} \mathrm{Ab}+$ asymptomatic individuals were cultured with a wide concentration range $(0.01-$ $20 \mu \mathrm{g} / \mathrm{ml}$ ) of purified and inactivated HIV-SF2 or with supernatant proteins of uninfected HUT-78 cells that were used for HIV propagation. Parallel cultures also contained an optimal concentration of rIL-2 $(5 \mathrm{U} / \mathrm{ml})$. Lymphocytes from all eight HIV $\mathrm{Ab}$ - individuals failed to proliferate in response to any concentration of HIV-SF2 or HUT-78 supernatant proteins in either the presence or absence of rIL-2 (Fig. $1 A$ ). Lymphocytes from only 1 of $10 \mathrm{HIV} \mathrm{Ab+asymptomatic} \mathrm{indi-}$ viduals exhibited significant proliferative responses $(P<0.001$ in comparison with HIV $\mathrm{Ab}$ - individuals) to HIV-SF2 (optimally at $10 \mu \mathrm{g} / \mathrm{ml}$ ) and this response was abrogated rather than augmented by the addition of rIL-2 (Fig. $1 B$ ). This asymptomatic individual's lymphocytes also proliferated in response to HIV-SF2 in the absence of added rIL-2 but not in its presence when tested 1 mo later. After an additional 5 mo his lymphocytes did not proliferate in response to HIV-SF2 either in the presence or absence of rIL-2 (data not shown). None of the HIV Ab+individuals' lymphocytes proliferated in response to HUT-78 proteins. Three HIV Ab+ asymptomatic individuals' lymphocytes were also cultured with infectious or inactivated HIV-SF2 at concentrations up to $50 \mu \mathrm{g} / \mathrm{ml}$, in both the pres-

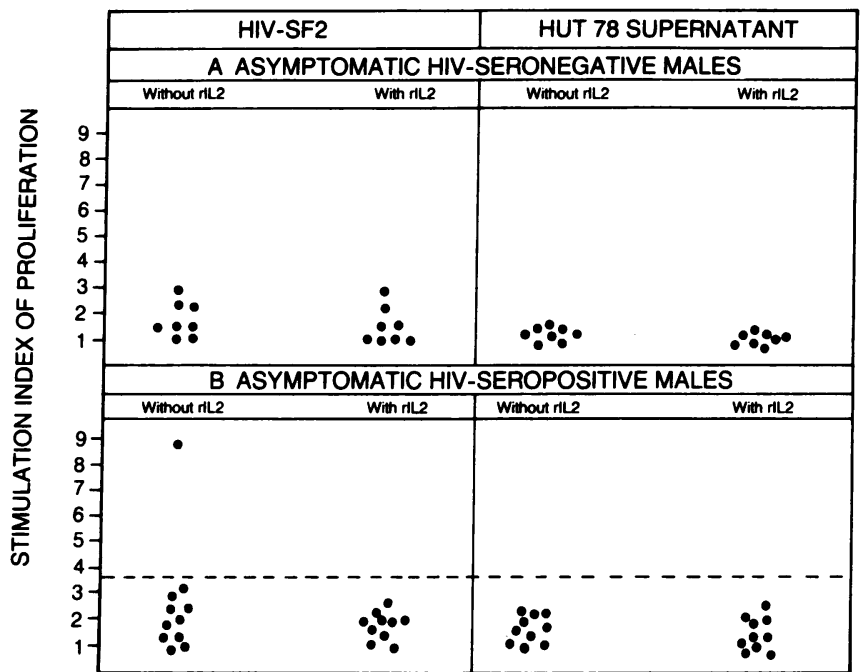

Figure 1. Lymphocyte proliferative responses to purified HIV-SF2 (see Fig. 2) and control proteins from HUT-78 supernatants. Each point represents one HIV $\mathrm{Ab}-$ or HIV $\mathrm{Ab}+$ asymptomatic study subject. Optimal proliferative responses to $0.01-20 \mu \mathrm{g} / \mathrm{ml}$ of purified HIV-SF2 or control proteins of HUT-78 cells in the presence or absence of rIL-2 $(5 \mathrm{U} / \mathrm{ml})$ were determined as described in Methods. All points above the horizontal dashed line are $>3 \mathrm{SD}$ above the mean stimulation index of HIV Ab- individuals' lymphocytes.

ence and absence of rIL-2, but failed to manifest significant proliferative responses (data not shown). Fig. 2 shows the results of Western blot analysis of the purified HIV-SF2 preparation used in these studies (Lane $A$ ). Although variable amounts of gp 160 were present in different preparations, all major proteins characteristic of HIV including gp 160, gp120, gp41, p31, and p25 were present in the material used for these lymphocyte proliferation studies.

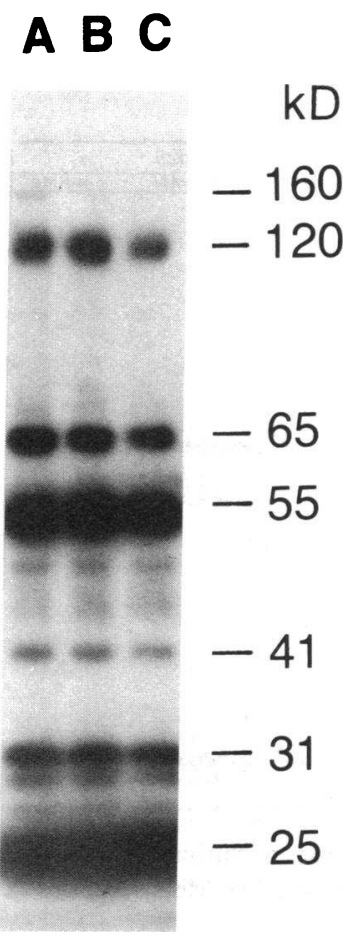

Figure 2. Western blot analysis of purified HIV-SF2. Three different preparations (Lanes $A-C$ ) of HIV-SF2 purified from infected HUT-78 cells as described (24) were subjected to Western analysis using sera from an HIV Ab+ male (12). Molecular weights of bands in kilodaltons are shown. 
Lymphocytes from most HIV Ab+ asymptomatic individuals and ARC patients do not proliferate in response to recombinant core or envelope subunit proteins of HIV-SF2. Lymphocytes from all $11 \mathrm{HIV} \mathrm{Ab-individuals} \mathrm{failed} \mathrm{to} \mathrm{proliferate}$ in response to any concentration $(0.01-20 \mu \mathrm{g} / \mathrm{ml})$ of recombinant p25 core protein of HIV-SF2 in either the presence or absence of rIL-2 (Fig. $3 \mathrm{~A}$ ). Most HIV Ab-individuals' lymphocytes, however, proliferated optimally in both the presence and absence of rIL-2 when cultured with doses between 0.01 and $20 \mu \mathrm{g} / \mathrm{ml}$ of a lysate of $E$. coli, the organism used to express the recombinant p25 protein (10). Only 2 of $11 \mathrm{HIV} \mathrm{Ab+}$ asymptomatic individuals' lymphocytes proliferated in response to p25 in the absence of rIL-2, and lymphocytes from these two and another individual proliferated when rIL-2 was added (Fig. $3 \mathrm{~A}$ ). Only 3 of 18 ARC patients' lymphocytes proliferated in response to p25 in the absence of rIL-2, and these responses were not augmented by the addition of rIL-2. Lymphocytes from one ARC patient proliferated in response to p25 in the presence of rIL-2 but not in its absence (Fig. $3 \mathrm{~A}$ ). In the absence of rIL-2, lymphocytes from 5 of $11 \mathrm{HIV} \mathrm{Ab+}$ asymptomatic individuals and 2 of $18 \mathrm{ARC}$ patients proliferated in response to $E$. coli antigens (Fig. $3 B$ ). Unlike the responses to p25, the responses of lymphocytes from many $\mathrm{HIV} \mathrm{Ab}+$ individuals to $E$. coli were augmented by the addition of rIL-2 (Fig. $3 \mathrm{~B}$ ). In the presence of rIL-2, 8 of 11 (72.7\%) HIV Ab+ asymptomatic individuals' and 14 of 18 (77.8\%) ARC patients' lymphocytes proliferated in response to E. coli.

All $11 \mathrm{HIV} \mathrm{Ab-individuals} \mathrm{failed} \mathrm{to} \mathrm{exhibit} \mathrm{lymphocyte}$ proliferation in response to any concentration of recombinant ENV2-3 that contains the protein backbone of gp120 (11), either in the presence or in the absence of rIL-2 (Fig. 4). Most HIV Ab- individuals' lymphocytes did, however, proliferate in response to a lysate of $S$. cerevisiae, which was used to express the recombinant ENV2-3 protein (11). 2 of $11 \mathrm{HIV}$ $\mathrm{Ab}+$ asymptomatic individuals' lymphocytes proliferated significantly $(P<0.01)$ in response to ENV2-3 in the absence of rIL-2. These two and another HIV Ab+ asymptomatic indi-

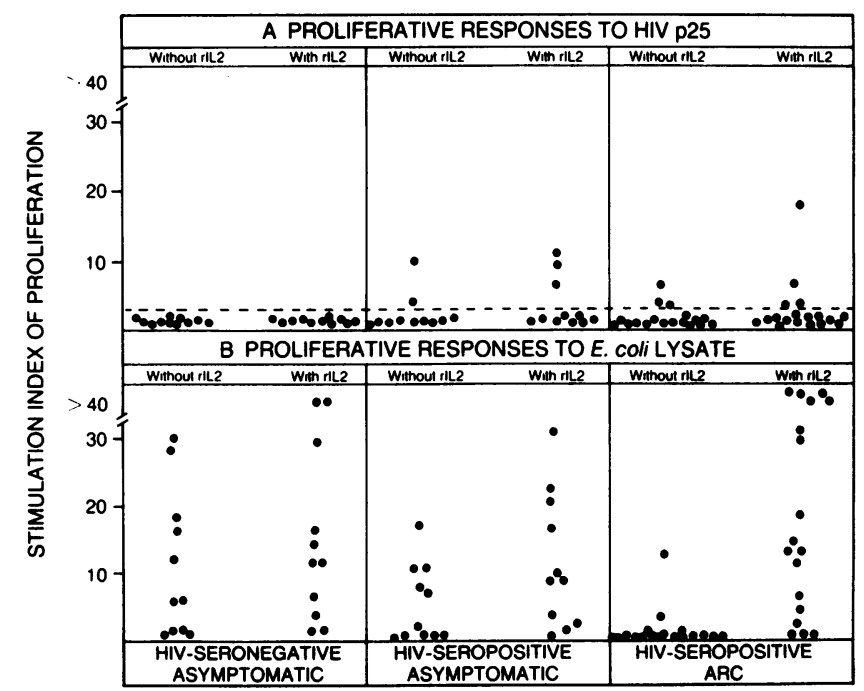

Figure 3. Lymphocyte proliferative responses to purified recombinant p25 of HIV-SF2 and E. coli extracts (10). See Methods and Fig. 1 legend.

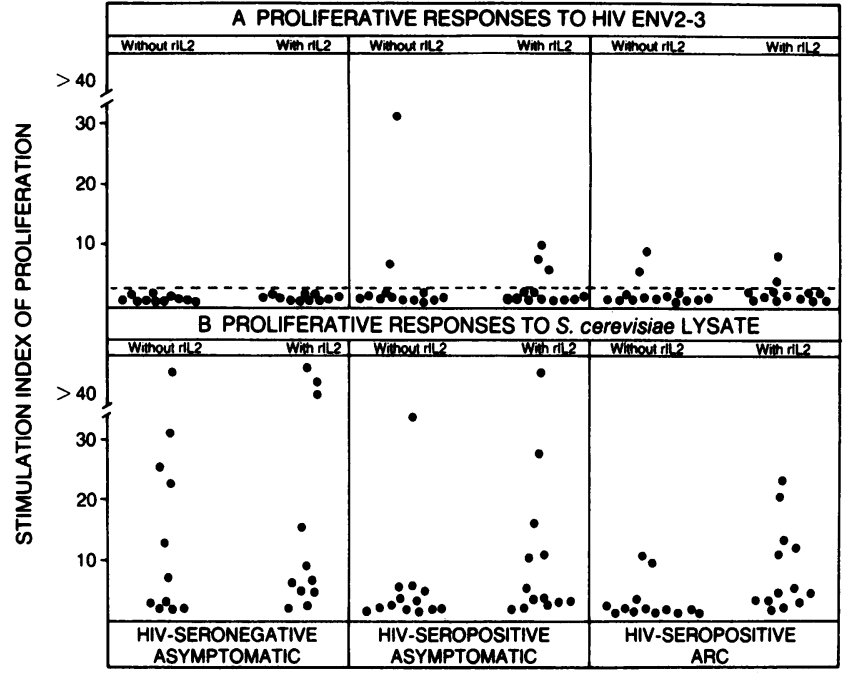

Figure 4. Lymphocyte proliferative responses to purified recombinant ENV2-3 envelope protein of HIV-SF2 and $S$. cerevisiae extracts (11). See Methods and Fig. 1 legend.

viduals' lymphocytes proliferated in response to ENV2-3 significantly in the presence of rIL-2. 2 of 13 ARC patients' lymphocytes proliferated in response to ENV2-3, but these responses were not augmented by the addition of rIL-2 (Fig. 4 $A)$. Similar to the responses of HIV Ab+ individuals to the $E$. coli lysate (Fig. $3 \mathrm{~B}$ ), proliferative responses of $\mathrm{HIV} \mathrm{Ab}+$ asymptomatic individuals' and ARC patients' lymphocytes to the $S$. cerevisiae lysate were often significantly augmented $(P$ $<0.01$ ) by the addition of rIL-2 (Fig. $4 \mathrm{~B}$ ).

Fig. 5 demonstrates that lymphocytes from all HIV Abindividuals, in either the presence or absence of rIL-2, failed to proliferate in response to any concentration of the ENV-5 fusion protein, which consists of part of SOD and a hydrophilic region of the protein backbone of gp41 (amino acids 557-677) of HIV-SF2 (11). Lymphocytes from all 13 HIV $\mathrm{Ab}+$ individuals and all $11 \mathrm{ARC}$ patients failed to proliferate

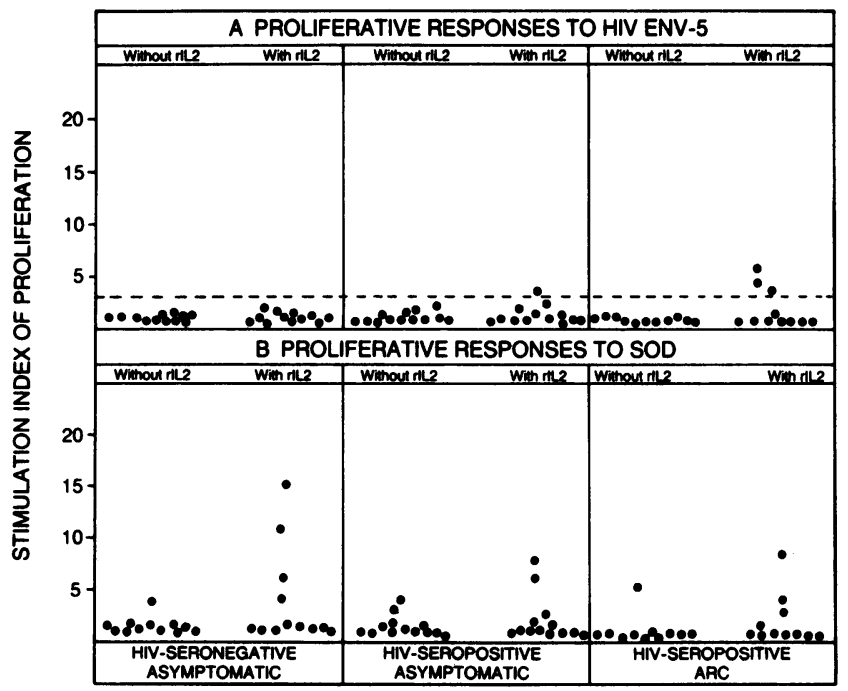

Figure 5. Lymphocyte proliferative responses to purified recombinant ENV-5 envelope fusion protein of HIV-SF2 and SOD (11). See Methods and Fig. 1 legend. 
in response to any concentration $(0.01-20 \mu \mathrm{g} / \mathrm{ml})$ of the ENV-5 fusion protein in the absence of rIL-2. In the presence of rIL-2, only one HIV Ab+ asymptomatic individual's lymphocytes and three ARC patients' lymphocytes demonstrated weak proliferative responses to ENV-5 that were significantly different from those of HIV Ab- individuals $(P<0.01)$. The proliferative responses of these $\mathrm{HIV} \mathrm{Ab}+$ asymptomatic individuals' and ARC patients' lymphocytes to SOD were also augmented by rIL-2. Proliferative responses to SOD were, however, augmented by rIL- 2 in only 3 of $12 \mathrm{HIV} \mathrm{Ab-} \mathrm{asymp-}$ tomatic individuals, 2 of $13 \mathrm{HIV} \mathrm{Ab+} \mathrm{asymptomatic} \mathrm{individ-}$ uals, and 2 of 11 ARC patients (Fig. $5 \mathrm{~B}$ ). Lymphocytes from $10 \mathrm{HIV} \mathrm{Ab}-$ and $10 \mathrm{HIV} \mathrm{Ab}+$ asymptomatic individuals also failed to proliferate when cultured with $0.01-20 \mu \mathrm{g} / \mathrm{ml}$ of ENV-1 (amino acids 26-276 of HIV-SF2) or with glycosylated recombinant gp120 of the HTLV-III isolate (26) expressed in mammalian cells (data not shown).

Recombinant ENV2-3 and p25 do not inhibit antigen- or mitogen-driven lymphocyte proliferative responses. Because of the low frequency of HIV Ab+ individuals who manifest lymphocyte proliferative responses to HIV proteins, we examined the possibility that recombinant ENV2-3 or p25 might suppress TT- and PHA-stimulated proliferation of lymphocytes from HIV $\mathrm{Ab}$ - individuals. Table I demonstrates that the nonglycosylated ENV2-3 or p25 do not suppress these antigenor mitogen-induced proliferative responses. The proliferative responses to TT or PHA in the absence of recombinant HIV proteins were not significantly different $(P>0.1)$ from the proliferative responses in the presence of $1-20 \mu \mathrm{g} / \mathrm{ml}$ of ENV2-3 or p25 (Table I). Moreover, as also shown in Figs. 3 and 4, lymphocytes from these and other HIV Ab-donors failed to proliferate in response to recombinant $\mathrm{p} 25$ or ENV2-3 proteins.

\section{Discussion}

Infection by viruses such as CMV or influenza characteristically induce lymphocytes capable of proliferating in vitro in response to the sensitizing viral antigens $(5,9,21,27)$. These proliferative responses are generally associated with the activity of CD4+ helper T lymphocytes $(4,28)$. In contrast to proliferative responses to other viruses, results presented in this report and elsewhere $(9,15,29)$ demonstrate that many HIVinfected individuals' lymphocytes fail to multiply in primary cultures in response to antigens of HIV. The results presented in this report and elsewhere $(15,29)$ demonstrate that the poor proliferative responses to HIV antigens occur not only when the antigens of HIV-SF2 are used for in vitro challenge but also in the presence of HTLV-III antigens. It is, therefore, unlikely that the defects observed in proliferative responses are merely due to polymorphism among proteins of divergent HIV-1 isolates, especially as many conserved regions of HIV envelope and core proteins are known to exist (30). The possibility that $T$ cells or antibodies recognizing polymorphic determinants of HIV antigens may not effectively recognize divergent HIV isolates, however, is an important consideration in the development of effective prophylaxis and therapy for HIV infections.

The selective nature of proliferative defects is evident in many HIV-infected individuals whose lymphocytes are competent to respond to other "recall" antigens. Furthermore, proliferative responses of HIV Ab+ asymptomatic individuals' and ARC patients' lymphocytes to other recall antigens but not to HIV can often be selectively restored by IL-2 (Figs. 3 and 4; references 5, 9, and 15). Lymphocytes from nearly all AIDS patients and from some other HIV-infected individuals are, however, unable to proliferate in response to any recall antigens, and these responses cannot generally be reconstituted with IL-2 $(4,5,15)$. In the early stages of HIV infection, selective defects in cell-mediated immune responses to HIV antigens may allow infection of susceptible cells by HIV. As more helper $\mathrm{T}$ cells are destroyed or inhibited by HIV in the course of infection these defects become nonselective, and eventually in AIDS these patients lose the ability of their lymphocytes to proliferate in response to any antigen $(4,5)$. These observations suggest that the ability of HIV to remain immunologically cryptic with respect to lymphocyte proliferation is an important factor in the pathobiology of HIV infections.

Table I. Recombinant ENV2-3 and p25 Proteins of HIV-SF2 Do Not Inhibit Antigen- or Mitogen-driven Lymphocyte Proliferation

\begin{tabular}{|c|c|c|c|c|c|}
\hline \multicolumn{3}{|c|}{ HIV Ab- donor 1} & \multicolumn{3}{|c|}{ HIV Ab- donor 2} \\
\hline \multirow[b]{2}{*}{ Antigen(s) or mitogens } & \multicolumn{2}{|c|}{$\begin{array}{c}{\left[{ }^{3} \mathrm{H}\right] \text { Thymidine }} \\
\text { incorporated by PBMC }\end{array}$} & \multirow[b]{2}{*}{ Antigen(s) or mitogens } & \multicolumn{2}{|c|}{$\begin{array}{c}{\left[{ }^{3} \mathrm{H}\right] \text { Thymidine }} \\
\text { incorporated by PBMC }\end{array}$} \\
\hline & CPM & SI & & CPM & SI \\
\hline None & 791 & 1 & None & 818 & 1 \\
\hline $\mathrm{TT}(2.5 \mathrm{Lf} / \mathrm{ml})$ & 31,469 & 39.7 & $\mathrm{TT}(2.5 \mathrm{Lf} / \mathrm{ml})$ & 43,361 & 53.0 \\
\hline TT + ENV2-3 (1 $\mu \mathrm{g} / \mathrm{ml})$ & 31,640 & 40.0 & $\mathrm{TT}+\mathrm{p} 25(1 \mu \mathrm{g} / \mathrm{ml})$ & 43,484 & 53.1 \\
\hline TT + ENV2-3 $(10 \mu \mathrm{g} / \mathrm{ml})$ & 33,612 & 42.5 & $\mathrm{TT}+\mathrm{p} 25(10 \mu \mathrm{g} / \mathrm{ml})$ & 46,698 & 57.0 \\
\hline TT + ENV2-3 $(20 \mu \mathrm{g} / \mathrm{ml})$ & 30,017 & 37.9 & $\mathrm{TT}+\mathrm{p} 25(20 \mu \mathrm{g} / \mathrm{ml})$ & 45,257 & 55.3 \\
\hline PHA (1\%) & 26,978 & 34.1 & PHA (1\%) & 24,528 & 29.9 \\
\hline PHA + ENV2-3 $(1 \mu \mathrm{g} / \mathrm{ml})$ & 26,300 & 33.2 & $\mathrm{PHA}+\mathrm{p} 25(1 \mu \mathrm{g} / \mathrm{ml})$ & 25,543 & 31.2 \\
\hline PHA + ENV2-3 $(10 \mu \mathrm{g} / \mathrm{ml})$ & 25,027 & 31.6 & PHA + p25 $(10 \mu \mathrm{g} / \mathrm{ml})$ & 23,910 & 29.2 \\
\hline PHA + ENV2-3 $(20 \mu \mathrm{g} / \mathrm{ml})$ & 27,244 & 34.4 & $\mathrm{PHA}+\mathrm{p} 25(20 \mu \mathrm{g} / \mathrm{ml})$ & 25,902 & 31.6 \\
\hline ENV2-3 $(20 \mu \mathrm{g} / \mathrm{ml})$ & 923 & 1.2 & p25 $(20 \mu \mathrm{g} / \mathrm{ml})$ & 898 & 1.1 \\
\hline
\end{tabular}

Recombinant envelope (ENV2-3) and core (p25) proteins of $\operatorname{HIV}(10,11,14)$ were analyzed for their ability to inhibit proliferative responses to TT or PHA as described in Methods. The cpm and SI of $\left[{ }^{3} \mathrm{H}\right]$ thymidine incorporated are reported. 
The results presented in this report and elsewhere $(9,15$, 29) demonstrate that at least some HIV-infected individuals can manifest lymphocyte proliferative responses to HIV or its subunits. In our studies (Fig. 1 and reference 9) only one individual has been detected whose lymphocytes proliferated in response to whole purified HIV. The reproducible abrogation of this response by rIL-2 may be attributable to rIL-2-induced alteration of the kinetics of proliferation or to enhancement of HIV replication by cellular activation (31). Longitudinal studies of responders to HIV or its subunits indicate that these responses are transient in nature (unpublished observations). Studies by Zagury and colleagues also indicate that even in an $\mathrm{HIV} \mathrm{Ab}$ - individual who was inoculated with an HIV vaccine, in vitro proliferative responses to HIV were only detectable for a few months after primary or subsequent immunizations (32). Thus, unlike infections by CMV or influenza $(5,21,27)$, HIV does not appear to induce long-lasting memory helper $\mathrm{T}$ cells that are capable of proliferation in vitro.

Studies by Wahren and colleagues (15) indicate a higher frequency of HIV Ab+ individuals whose lymphocytes proliferate in response to some HIV antigens, particularly p25, than were observed in our study. As their study did not include HIV $\mathrm{Ab}$ - homosexuals in their control group and also did not exclude the possibility of antigenic contaminants from $E$. coli or other cells in their recombinant HIV antigen preparations, their results are difficult to interpret. Nevertheless, the results of this report and others $(9,15,29)$ indicate selective defects in lymphocyte proliferative responses to at least some HIV antigens in infected humans. In contrast to the paucity of lymphocyte proliferative responses to HIV antigens in infected humans (Figs. 1, 3-5 and reference 9), most HIV-infected or immunized chimpanzees manifest proliferative responses to HIV antigens $(9,33)$. These results suggest that the proliferative responses of HIV-infected chimpanzees may play a role in the resistance to HIV disease of these HIV-infected animals.

The reasons for the selective defects in proliferative responses to HIV antigens of lymphocytes from HIV-infected humans are not clear. The cytopathic effects of HIV on CD4+ $T$ cells (3) suggest that infection and subsequent depletion of HIV-reactive CD4+ T cells may contribute to defects in proliferative responses to HIV and other antigens. The defects in proliferative responses to HIV or other antigens can not, however, be explained simply as the result of decreased levels of $\mathrm{CD} 4+\mathrm{T}$ cells. Lymphocytes from HIV Ab+individuals with relatively normal levels of CD4+ T cells $(600-1,000 / \mu \mathrm{l})$ often failed to proliferate in response to any of the HIV antigens tested, although they were capable of proliferating in response to PHA or other recall antigens (11, and unpublished observations). Considerable variability was observed in the absolute numbers of percentages of CD4+ and CD8+ lymphocytes from individuals that manifested proliferative responses to HIV antigens (unpublished observations). Other studies have also demonstrated only weak correlations between lymphocyte subset values and proliferative responses to CMV or PHA in HIV $\mathrm{Ab}+$ individuals $(5,34)$.

Although the immunosuppressive effects of HIV, its gp120, or synthetic peptides derived from HIV gp41 have been demonstrated in vitro $(5,9,35)$, their effects in vivo are not known. The binding of gp120 to CD4+ T cells in vivo may inhibit responsiveness of these cells to HIV or other antigens in vitro. Data in this report and elsewhere (15), however, show that primary in vitro responses to HIV antigens, unlike gp120-suppressed responses to other antigens such as CMV (5), are rarely augmented by rIL- 2 . In contrast to the suppression of immune responses by glycosylated gp120 (5), a nonglycosylated form of yeast-expressed HIV gp120 (ENV2-3, references 11 and 14) did not inhibit PHA- or antigen-driven lymphocyte proliferation (Table I). This finding suggests that the sugar residues of gp120 may be important in its biological effects either by direct interaction of these sugars with CD4 or by maintaining functionally important molecular conformations of gp120 epitopes. Additional studies directly comparing glycosylated and nonglycosylated forms of the external envelope glycoproteins of HIV-SF2 and other isolates are necessary to confirm and elucidate the roles of carbohydrates in $\mathrm{gp} 120$ mediated suppression of lymphocyte proliferation.

The studies in this report demonstrate that HIV infections, unlike those of CMV or influenza $(5,9,27)$, do not usually induce long-lasting lymphocytes capable of proliferating in vitro in response to the cognate viral antigens. Additional analysis of methods to effectively stimulate cell-mediated responses to HIV antigens may have important applications in the design of vaccines and immunotherapy for HIV infections. Nonglycosylated HIV envelope proteins or synthetic peptide subunits may overcome the potential problems associated with the use of an immunosuppressive gp 120 moiety in prophylactic or therapeutic AIDS vaccines.

\section{Acknowledgments}

We are grateful to Dr. A. Ammann (Genentech Inc., South San Francisco, CA) for providing glycosylated recombinant gp 120. C. Anderson provided excellent assistance in the typing of this manuscript. We are grateful to the staff of the AIDS clinics at the University of California, San Francisco, and the San Francisco General Hospital, particularly T. Johnson, S. Stringari, and S. McDowell, for their help. The cooperation of our study subjects is also appreciated greatly.

This work was supported by grants from the California Universitywide AIDS Task Force and by grants CA-34980, HL/AI-32477, AI-24286, and IR-43AI2277801 from the National Institutes of Health.

\section{References}

1. Centers for Disease Control. 1987. Revision of the CDC surveillance case definition for acquired immunodeficiency syndrome. Morbid. Mortal. Weekly Rep. 36:1-15.

2. Moss, A. R., P. Bacchetti, D. Osmond, W. Krampf, R. Chaisson, D. P. Stites, J. Wilber, J.-P. Allain, and J. R. Carlson. 1988. Seropositivity for HIV and the development of AIDS or AIDS related condition: three year followup of the San Francisco General Hospital cohort. Br. Med. J. 296:745-750.

3. Klatzmann, D., F. Barré-Sinoussi, M. T. Nugeyre, C. Dauguet, E. Vilmer, C. Griscelli, F. Brun-Vezinet, C. Rouzioux, J. C. Gluckman, J.-C. Chermann, and L. Montagnier. 1984. Selective tropism of lymphadenopathy associated virus (LAV) for helper-inducer T lymphocytes. Science (Wash. DC). 225:59-63.

4. Lane, H. C., J. M. Depper, W. C. Greene, G. Whalen, T. A. Waldman, and A. S. Fauci. 1985. Qualitative analysis of immune function in patients with the acquired immunodeficiency syndrome: evidence for a selective defect in soluble antigen recognition. $N$. Engl. J. Med. 313:79-84.

5. Krowka, J. F., D. P. Stites, J. Mills, H. Hollander, T. McHugh, M. Busch, L. Wilhelm, and L. Blackwood. 1988. Effects of interleukin 2 and large envelope glycoprotein (gp120) of human immunodefi- 
ciency virus (HIV) on lymphocyte proliferative responses to cytomegalovirus. Clin. Exp. Immunol. 72:179-185.

6. Nicholson, J. K., G. D. Cross, C. S. Callaway, and J. S. McDougal. 1986. In vitro infection of human monocytes with the human $T$ lymphotropic virus type III/lymphadenopathy-associated virus (HTLV-III/LAV). J. Immunol. 137:323-329.

7. Shannon, K., M. J. Cowan, E. Ball, D. Abrams, P. Volberding, and A. J. Ammann. 1985. Impaired mononuclear-cell proliferation in patients with the acquired immune deficiency syndrome results from abnormalities of both $\mathrm{T}$ lymphocytes and adherent mononuclear cells. J. Clin. Immunol. 5:239-245.

8. Petit, J. C., M. Tersmette, F. G. Terpstra, R. E. de Goode, R. A. van Lier, and F. Miedema. 1988. Decreased accessory cell function by human monocytic cells after infection with HIV. J. Immunol. 140:1485-1489.

9. Krowka, J. F., D. M. Moody, and D. P. Stites. 1988. Immunological effects of HIV infection. In AIDS: Pathogenesis and Treatment. J. A. Levy, editor. Marcel Dekker, Inc., New York. 257-303.

10. Steimer, K. S., J. P. Puma, M. D. Powers, C. George-Nascimento, J. C. Stephans, J. A. Levy, R. Sanchez-Pescador, P. A. Luciw, P. J. Barr, and R. A. Hallewell. 1986. Differential antibody responses of individuals infected with AIDS-associated retroviruses using the viral core antigen p25gag expressed in bacteria. Virology. 150:283290.

11. Barr, P. J., K. S. Steimer, E. A. Sabin, D. Parkes, C. GeorgeNascimento, J. L. Stephans, M. A. Powers, A. Gyenes, G. A. Van Nest, E. T. Miller, K. W. Higgins, and P. A. Luciw. 1987. Antigenicity and immunogenicity of domains of the human immunodeficiency virus (HIV) envelope polypeptide expressed in the yeast Saccharomyces cerevisiae. Vaccine. 5:90-101.

12. Carlson, J. R., M. L. Bryant, S. H. Hinrichs, J. K. Yamamoto, N. B. Levy, J. Higgins, A. M. Levine, P. Holland, M. B. Gardner, and N. C. Pedersen. 1985. AIDS serology testing in low- and high-risk groups. JAMA (J. Am. Med. Assoc.). 253:3405-3408.

13. Kaminsky, L. S., T. McHugh, D. Stites, P. Volberding, G. Henle, W. Henle, and J. A. Levy. 1985. High prevalence of antibodies to acquired immune deficiency syndrome (AIDS)-associated retrovirus (ARV) in AIDS and related conditions but not in other disease states. Proc. Natl. Acad. Sci. USA. 82:5535-5539.

14. Steimer, K. S., G. Van Nest, D. Dina, P. J. Barr, P. A. Luciw, and E. T. Miller. 1987. Genetically engineered human immunodeficiency virus envelope glycoprotein gp120 produced in yeast is the target of neutralizing antibodies. In Vaccines 87. R. M. Chanock, R. A. Larner, F. Brown, and H. Ginsberg, editors. Cold Spring Harbor Laboratory, Cold Spring Harbor, NY. 236-241.

15. Wahren, B., L. Morfeld-Mansson, G. Biberfield, L. Moberg, A. Sonnerborg, P. Ljungman, A. Warner, R. Kurch, R. Gallo, and D. Bolognesi. 1987. Characteristics of the specific cell-mediated immune response in human immunodeficiency virus infection. $J$. Virol. 61:2017-2023.

16. Walker, B. D., S. Chakrabarti, B. Moss, T. J. Paradis, T. Flyhn, A. G. Durno, R. S. Blumberg, J. C. Kaplan, M. S. Hirsch, and R. T. Schooley. 1987. HIV-specific cytotoxic T lymphocytes in seropositive individuals. Nature (Lond.). 328:345-348.

17. Ojo-Amaize, E. A., P. Nishanian, D. E. Kerth, R. L. Houghton, D. F. Heitjan, J. L. Fahey, and J. F. Giorgi. 1987. Antibodies to human immunodeficiency virus in human sera induce cell-mediated lysis of human immunodeficiency virus-infected cells. J. Immunol. 139:2458-2463.

18. Walker, B. D., C. Flexner, T. J. Paradis, T. C. Fuller, M. S. Hirsch, R. T. Schooley, and B. Moss. 1988. HIV-1 reverse transcriptase is a target for cytotoxic $T$ lymphocytes in infected individuals. Science (Wash. DC). 240:64-66.

19. Weinhold, K. J., T. J. Matthews, P. M. Abearne, A. Langlois, K. H. Lyerly, D. S. Tyler, K. C. Stine, D. T. Durack, and D. P. Bolognesi. 1988. Cellular anti-gp120 cytolytic reactivites in HIV-1 seropositive individuals. Lancet. i:902-905.
20. Yap, K. L., and G. L. Ada. 1978. The recovery of mice from influenza virus infection: adoptive transfer of immunity with immune T lymphocytes. Scand. J. Immunol. 7:389-397.

21. Quinnan, G. V., N. Kirmani, A. H. Rook, J. F. Manischewitz, L. Jackson, G. Moreschi, G. W. Santos, and R. Saral. 1982. Cytotoxic $T$ cells in cytomegalovirus infection: HLA-restricted T-lymphocyte and non-T-lymphocyte cytotoxic responses correlate with recovery from cytomegalovirus infection in bone-marrow transplant recipients. N. Engl. J. Med. 307:7-13.

22. Earl, P. L., B. Moss, R. P. Morrison, K. Wehrly, J. Nishio, and B. Chesebro. 1986. T-lymphocyte priming and protection against friend leukemia by vaccinia-retrovirus env gene recombinant. Science (Wash. DC). 234:728-731.

23. Levy, J. A., A. D. Hoffman, S. M. Kramer, J. A. Landis, and J. M. Shimabukuro. 1984. Isolation of lymphocytopathic retroviruses from San Francisco patients with AIDS. Science (Wash. DC). 225:840-842.

24. McGrath, M., O. Witte, T. Pincus, and I. L. Weissman. 1978. Retrovirus purification: method that conserves envelope glycoprotein and maximizes infectivity. J. Virol. 25:923-928.

25. Gillis, S., and K. A. Smith. 1977. Long-term culture of tumour-specific cytotoxic T cells. Nature (Lond.). 268:154-156.

26. Lasky, L. A., J. E. Groopman, C. W. Fennie, P. M. Benz, D. J. Capon, D. J. Dowbenko, G. R. Nakamura, W. M. Nunes, M. E. Renz, and P. W. Berman. 1986. Neutralization of the AIDS retrovirus by antibodies to a recombinant envelope glycoprotein. Science (Wash. DC). 223:209-212.

27. Lamb, J. R., J. N. Woody, R. J. Harzman, and D. D. Eckels. 1982. In vitro influenza virus-specific antibody production in man: antigen-specific and HLA-restricted induction of helper activity mediated by cloned human T lymphocytes. J. Immunol. 129:1465-1470.

28. Engleman, E. G., C. J. Benike, F. C. Grumet, and R. L. Evans. 1981. Activation of human T lymphocyte subsets: helper and suppressor/cytotoxic T cells recognize and respond to distinct histocompatibility antigens. J. Immunol. 127:2124-2129.

29. Wahren, B., L. Morfeld-Mansson, G. Biberfeld, L. Moberg, P. Ljungman, S. Nordlund, U. Bredberg-Raden, A. Werner, J. Lower, and R. Kurth. 1986. Impaired specific cellular response to HTLV-III before other immune defects in patients with HTLV-III infection. $N$. Engl. J. Med. 315:393-394.

30. 1988. Human Retroviruses and AIDS. G. Myers, A. B. Rabson, S. F. Josephs, T. F. Smith, and F. Wong-Staal, editors. Los Alamos National Laboratory, Los Alamos, NM.

31. Tong-Starksen, S. E., P. A. Luciw, and B. M. Peterlin. 1987. Human immunodeficiency virus long terminal repeat responds to Tcell activation signals. Proc. Natl. Acad. Sci. USA. 84:6845-6849.

32. Zagury, D., J. Bernard, R. Cheynier, I. Desportes, R. Leonard, M. Fouchard, B. Reveil, D. Ittale, Z. Lurhuma, K. Mbayo, J. Wayne, J.-J. Salaun, B. Goussard, L. Dechazal, A. Burny, P. Nara, and R. C. Gallo. 1988. A group specific anamnestic immune reaction induced by a candidate vaccine against AIDS. Nature (Lond.). 321:728-731.

33. Zarling, J. M., J. W. Eichberg, P. A. Moran, J. McClure, P. Sridhar, and S.-L. Hu. 1987. Proliferative and cytotoxic T cells to AIDS virus glycoproteins in chimpanzees immunized with a recombinant vaccinia virus expressing AIDS virus envelope glycoproteins. $J$. Immunol. 139:988-990.

34. Gluckman, J.-L., D. Klatzmann, M. Cavaille-Coll, E. Brisson, A. Messiah, D. Lachiver, and W. Rozenbaum. 1985. Is there correlation of $T$ cell proliferative functions and surface marker phenotypes in patients with acquired immune deficiency syndrome or lymphadenopathy syndrome? Clin. Exp. Immunol. 60:8-16.

35. Chanh, T. C., R. C. Kennedy, and P. Kanda. 1988. Synthetic peptides homologous to HIV transmembrane glycoprotein suppress normal human lymphocyte blastogenic response. Cell. Immunol. 111:77-86. 